Article

\title{
Long-Term Productivity of Thirteen Lowland and Upland Switchgrass Ecotypes in the Mediterranean Region
}

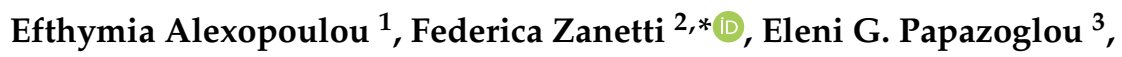 \\ Konstantinos Iordanoglou ${ }^{1}$ and Andrea Monti ${ }^{2}$ \\ 1 Centre for Renewable Energy Sources and Saving, 19009 Pikermi, Greece; ealex@cres.gr (E.A.); \\ kostasjord@gmail.com (K.I.) \\ 2 Department of Agriculture and Food Sciences, Alma Mater Studiorum-Università di Bologna, \\ 40127 Bologna, Italy; a.monti@unibo.it \\ 3 Department of Crop Science, Agricultural University of Athens, 11855 Athens, Greece; elpapazo@aua.gr \\ * Correspondence: federica.zanetti5@unibo.it; Tel.: +390512096655
}

Received: 25 May 2020; Accepted: 25 June 2020; Published: 27 June 2020

check for updates

\begin{abstract}
Switchgrass (Panicum virgatum L.) has been identified in the USA as an ideal biomass crop, in relation to its wide environmental suitability, mainly linked to the availability of both upland and lowland ecotypes, allowing the possibility of growing this species in most of the North American region. Switchgrass is conventionally grown for forage, but more recently, it has been considered as a model biofuel crop. Early European studies on switchgrass as a bioenergy crop started in the late 1990s, when a multi-location field trial was established in Greece (Aliartos) and Italy (Ozzano) to compare the productivity of 13 switchgrass genotypes, including upland (Carthage, Blackwell, Caddo, CIR, Forestburg, SU 94-1, Summer) and lowland (Alamo, Kanlow, Pangburn, SL 93-2, SL 93-3, SL94-1) genotypes. The scope was to identify the most suitable ecotype within each environment and, possibly, the best performing variety. The trials lasted 17 years (1998-2014) in Greece and 13 years (1998-2010) in Italy. While in Italy the trial was rainfed and unfertilized, in Greece, where the soil was marginal, drip irrigation was always applied, and the plots were fertilized regularly. The biomass yields in Greece, as averages across the 17 years, were similar for the lowland and upland varieties (11.5 vs. $11.1 \mathrm{Mg} \mathrm{ha}^{-1}$, respectively), while in Italy, as averages across the 13 years, the differences were relevant: 15.4 vs. $11.3 \mathrm{Mg} \mathrm{ha}^{-1}$ for lowland and upland, respectively. Alamo (lowland) was the most productive variety, both in Greece and Italy, with average annual yields of 12.7 and $16.6 \mathrm{Mg} \mathrm{ha}^{-1}$, respectively; CIR in Greece (10.1 Mg ha ${ }^{-1}$ ) and Forestburg in Italy $\left(9.1 \mathrm{Mg} \mathrm{ha}^{-1}\right.$ ) (both upland) were the least productive genotypes. The present results demonstrate the good suitability of switchgrass as biomass crop for the Mediterranean climate. Despite the very marginal soil (i.e., very shallow and with a sandy texture) in the Greek trial, the application of regular fertilization and irrigation produced biomass yields above $11 \mathrm{Mg} \mathrm{ha}^{-1}$ (grand mean) in the present 17-year-long study.
\end{abstract}

Keywords: perennial grass; biomass yield; plant height; tiller density; advanced biofuels; stand duration

\section{Introduction}

Switchgrass (Panicum virgatum L.) is a C4 perennial grass and one of the predominant native species of the North American tallgrass prairies. This species gained attention in USA as a warm-season pasture grass for fodder production in areas where C3 plants were less productive. Almost 30 years ago, the USDA-DOE identified switchgrass as a promising herbaceous species for bioenergy feedstock production [1]. Early European studies on switchgrass as an energy feedstock started in the late 1990s [2] 
and later continued within several EU research projects [3-7]. Switchgrass has relatively low input requirements, and it was found to be suited to marginal land less suitable for food production $[4,8,9]$, avoiding/reducing food vs. fuel competition.

Apparently, switchgrass as a biomass crop has an economic lifespan of about 10-15 years, and such a value is generally taken for predicting its economic and environmental impacts [10-12]. However, there is no clear evidence of the real economic lifespan of switchgrass in the literature, with no or very few papers showing yield results from long-term ( $>10-15$ years) field cultivations of switchgrass $[4,13]$. Therefore, despite its importance for economic and environmental assessment studies, the economic life of switchgrass still remains an uncertain issue and should be investigated. It was reported in [11] that a yearly productivity above $10 \mathrm{Mg} \mathrm{DM} \mathrm{ha}^{-1}$, with an average biomass cost ranging between 55 and 75 EUR $\mathrm{Mg}^{-1}$, represents the breakeven yield for switchgrass when grown on marginal land in Southern Europe; however, the level of agronomic management in terms of the inputs applied would significantly affect the revenues for farmers.

The availability of two distinct ecotypes, lowland and upland, derived from the natural adaptation to/selection for different environments, with distinct genetic and morphological characteristics [14-16], tremendously enlarges the potential growing areas for switchgrass. The lowland ecotype performs well in humid, warm environments, and its specific characteristics are an early starting of regrowth, late flowering, thick stems, tall plants, and a high dry matter yield [17]. The upland ecotype is more adapted to cold and semi-arid climates, tends to grow shorter, and is less coarse than the lowland type [17]. The availability of many switchgrass varieties within each ecotype makes feasible its cultivation in most European countries. In the late 1990s, a number of field trials were established in five European countries (the Netherlands, the UK, Greece, Germany and Italy) to test the suitability and productivity of switchgrass in Europe (see www.switchgrass.nl, for an extended review). Very few trials have been carried out with tenacity for more than ten years, even without any public or third-party funding whatsoever. In the present paper, we report and discuss the results of two long-term trials in Greece (1998-2014) and Italy (1998-2010) comparing thirteen switchgrass varieties (including both lowlands and uplands, Table 1). This will enable an improved understanding of the productivity and economic lifespan of switchgrass as a biomass crop in Southern Europe. 
Table 1. Ecotype, ploidy level, origin, 100-seed weight, and short description of the thirteen switchgrass varieties tested in Greece and Italy.

\begin{tabular}{|c|c|c|c|c|c|}
\hline Variety & Ploidy & Origin & Maturity & 100-Seed Weight (mg) & Description/Selection \\
\hline \multicolumn{6}{|c|}{ Lowland } \\
\hline Alamo [18-20] & $4 \mathrm{X}$ & South Texas $27^{\circ}$ & Very late & 94 & $\begin{array}{l}\text { Selected for its high forage potential. Up to } 2.5 \mathrm{~m} \text { high with wide leaves. It has late } \\
\text { maturity. Alamo was a USDA NRCS release from Knox City Texas. }\end{array}$ \\
\hline Kanlow [18-20] & $4 \mathrm{X}$ & Central Oklahoma $\sim 34.8^{\circ}$ & Very late & 85 & $\begin{array}{l}\text { Selected for leafiness, vigor, and retention of green leaf blades late in season. It is a tall } \\
\text { coarse type adapted to lowlands with high water tables but performs well on upland } \\
\text { soils. It was released by USDA NRCS (Kansas Agricultural Experiment Station). }\end{array}$ \\
\hline Pangburn [20] & $4 \mathrm{X}$ & Arkansas $\left(34^{\circ}\right)$ & & 96 & Developed at USDA-NRCS Plant Material Center, Cape May, N.J. \\
\hline SL 93-2 [21] & $4 X$ & \multirow{3}{*}{$26-30^{\circ}$} & & 87 & \multirow{3}{*}{$\begin{array}{l}\text { Developed at OSU by Taliaferro and Hopkins; derived from Alamo and } \\
\text { relative germplasms }\end{array}$} \\
\hline SL 93-3 [21] & $4 \mathrm{X}$ & & & 100 & \\
\hline SL 94-1 [21] & $4 \mathrm{X}$ & & & 91 & \\
\hline \multicolumn{6}{|c|}{ Upland } \\
\hline Blackwell [18-20] & $8 \mathrm{X}$ & Northern Oklahoma $\sim 36.7^{\circ}$ & Mid/late & 142 & $\begin{array}{l}\text { Has medium height with large and leafy stems. Although upland it can be grown on } \\
\text { lowland sandy areas. Total forage yield, disease resistance, and seedling vigor is good. } \\
\text { It was released by the USDA NRCS (Kansas Agricultural Experiment Station). }\end{array}$ \\
\hline Carthage $[18,22,23]$ & $8 \mathrm{X}$ & North Carolina $36^{\circ}$ & Late & 148 & $\begin{array}{l}\text { Grows better than CIR \& Blackwell in northern and mid-Atlantic areas in USA. High } \\
\text { protein content ( } 8-10 \%) \text {. It grows best on sandy to loamy soils and not well on heavier } \\
\text { soils. Carthage was released from the USDA NRCS, Cape May, New Jersey (2006). }\end{array}$ \\
\hline Caddo $[18-20,24]$ & $8 \mathrm{X}$ & Northern Oklahoma $\sim 34.8^{\circ}$ & Late & 159 & $\begin{array}{l}\text { Tall plant, robust, high seed production and outstanding forage yield under irrigation. } \\
\text { Excellent seedling vigor, resistant to leaf rust. }\end{array}$ \\
\hline $\begin{array}{c}\text { Cave-in-rock (CIR) } \\
{[18-20,25]}\end{array}$ & $8 \mathrm{X}$ & Southern Illinois 38. $8^{\circ}$ & Late & 166 & $\begin{array}{l}\text { Selected for seedling vigor, disease resistance, higher seed yields, and resistance to } \\
\text { lodging. It is tolerant to flooding but will also withstand droughty soils. Resistance to } \\
\text { zonate leafspot and rust, good in humid conditions. } 1.5 \mathrm{~m} \text { tall, well-drained soils, } \\
\text { moderate seedling vigor, coarser than Pathfinder and Blackwell. } \\
\text { Realized by USDA NRCS (Elsberry, Missouri and the Agricultural } \\
\text { Experiment Station). }\end{array}$ \\
\hline Forestburg $[18,19,26]$ & $4 \mathrm{X}$ & South Dakota $\sim 44.2^{\circ}$ & Early & 146 & $\begin{array}{l}\text { Mix of four accessions collected near the town of Forestburg. Selected for early cycle, } \\
\text { persistence, high forage yields and quality. At northern latitudes it's quite comparable } \\
\text { with Nebraska } 28 \text { and Sunburst. It was released by USDA NRCS and Agricultural } \\
\text { Research Service release. }\end{array}$ \\
\hline SU 94-1 [21] & $8 \mathrm{X}$ & Oklahoma & & 183 & Developed at OSU by Taliaferro and Hopkins \\
\hline Summer $[19,20]$ & $4 \mathrm{X}$ & South Nebraska $\sim 40.8^{\circ}$ & Late/mid & 113.5 & $\begin{array}{c}\text { Mostly rust resistant, tall for north, upright, coarse leaves, high yield of forage } \\
\text { and seed. }\end{array}$ \\
\hline
\end{tabular}




\section{Materials and Methods}

\subsection{Experimental Set Up}

Two similar screening trials were established in 1998 in the Mediterranean region. The first trial was established at Aliartos (Greece, 38 $22^{\prime} \mathrm{N}, 23^{\circ} 06^{\prime} \mathrm{E}$ ) and lasted 17 years (1998-2014). The second

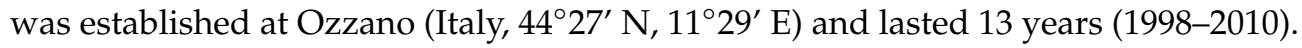

The soil in Aliartos was characterized as marginal and classified as Fluvisoil Redoximorphic. The texture was sandy loam (63\% sand, $12 \%$ clay, and $25 \%$ loam) with a very low organic matter content $(0.5 \%)$ and $\mathrm{pH}$ of 8 . The experimental site was located on the bank of a former lake, drained at the end of 19th century, and due to this, the soil depth was just $0.5 \mathrm{~m}$, and below, there was only sand. The soil in Ozzano was classified as Udifluventic Haplustepts. The texture was clay loam ( $34 \%$ sand, $37 \%$ clay, and $29 \%$ loam) with a medium-low organic matter content (1.2\%) and $\mathrm{pH}$ of 7.7 . Although both sites belong to the Mediterranean climatic zone, Aliartos is further classified as being in a southern Mediterranean climate, while Ozzano is classified as being in a northern Mediterranean climate [27]. Meteorological data, including the air temperature (minimum and maximum) and precipitation, were collected by weather stations located near $(<20 \mathrm{~km})$ to each experimental location. Due to the high temperatures (e.g., the maximum temperature often exceeded $35^{\circ} \mathrm{C}$ ) and the prolonged drought periods during summer (Figure 1), in the Greek experimental site, irrigation was applied every year by means of a drip system. The supplied amount was targeted to ensure a total of $350 \mathrm{~mm}$ of water-including precipitation-was supplied to the stand in the April-to-September period. The abovementioned water need was defined as the minimum value to obtain an adequate yield in a shallow soil like that of Aliartos, in agreement with [28]. In Italy, $60 \mathrm{~mm}$ of water, by means of a sprinkle irrigation system, were applied to promote switchgrass establishment in spring 1998; thereafter. the stand was rainfed. In both trials, a total number of 13 varieties (six lowlands and seven uplands) were sown at the beginning of May, under optimal temperature conditions as identified for switchgrass (soil temperature $>10^{\circ} \mathrm{C}$ ). The full characterization (ecotype, ploidy level, origin, maturity type, and 100-seed weight) of the tested switchgrass varieties is presented in Table 1 . At both locations, the soil was prepared by means of moldboard ploughing ( $0.40 \mathrm{~m}$ depth) and secondary rotary tillage to produce a firm seedbed with a fine textural surface. The plots were seeded at a $10 \mathrm{~mm}$ depth with a rate of 500 PLS (Pure Live Seed) per square meter. After seeding, the soil was rolled to ensure good seed-soil contact. The distance between the rows was $0.15 \mathrm{~m}$, the plot size was $15 \mathrm{~m}^{2}(5 \mathrm{~m} \times 3 \mathrm{~m})$, and the experimental design was a randomized complete block with three replicates at both sites. The full agronomic management for the trial at Aliartos has been reported by [3] and included the application of 2.4-D herbicide (at a dose of $450 \mathrm{~g} \mathrm{ha}^{-1}$ ) after switchgrass sowing; otherwise, in Ozzano, neither the chemical nor manual control of weeds was carried out. In Greece, every year after the beginning of the spring re-growth, nitrogen, at the rate of $75 \mathrm{~kg} \mathrm{~N} \mathrm{ha}^{-1}$ as ammonium nitrate, was applied by means of the drip irrigation system. Furthermore, every 5 years (i.e., in 2003, 2008, and 2013), basic fertilization was applied at the rate of 33, 45 , and $45 \mathrm{~kg} \mathrm{ha}^{-1}$ for $\mathrm{N}, \mathrm{P}$, and $\mathrm{K}$, respectively, and in these years, the ammonium nitrate fertilization was skipped. In Italy, fertilization was applied just before sowing at a rate of 60 and $80 \mathrm{~kg} \mathrm{ha}^{-1}$ for N and $\mathrm{P}$, respectively. 

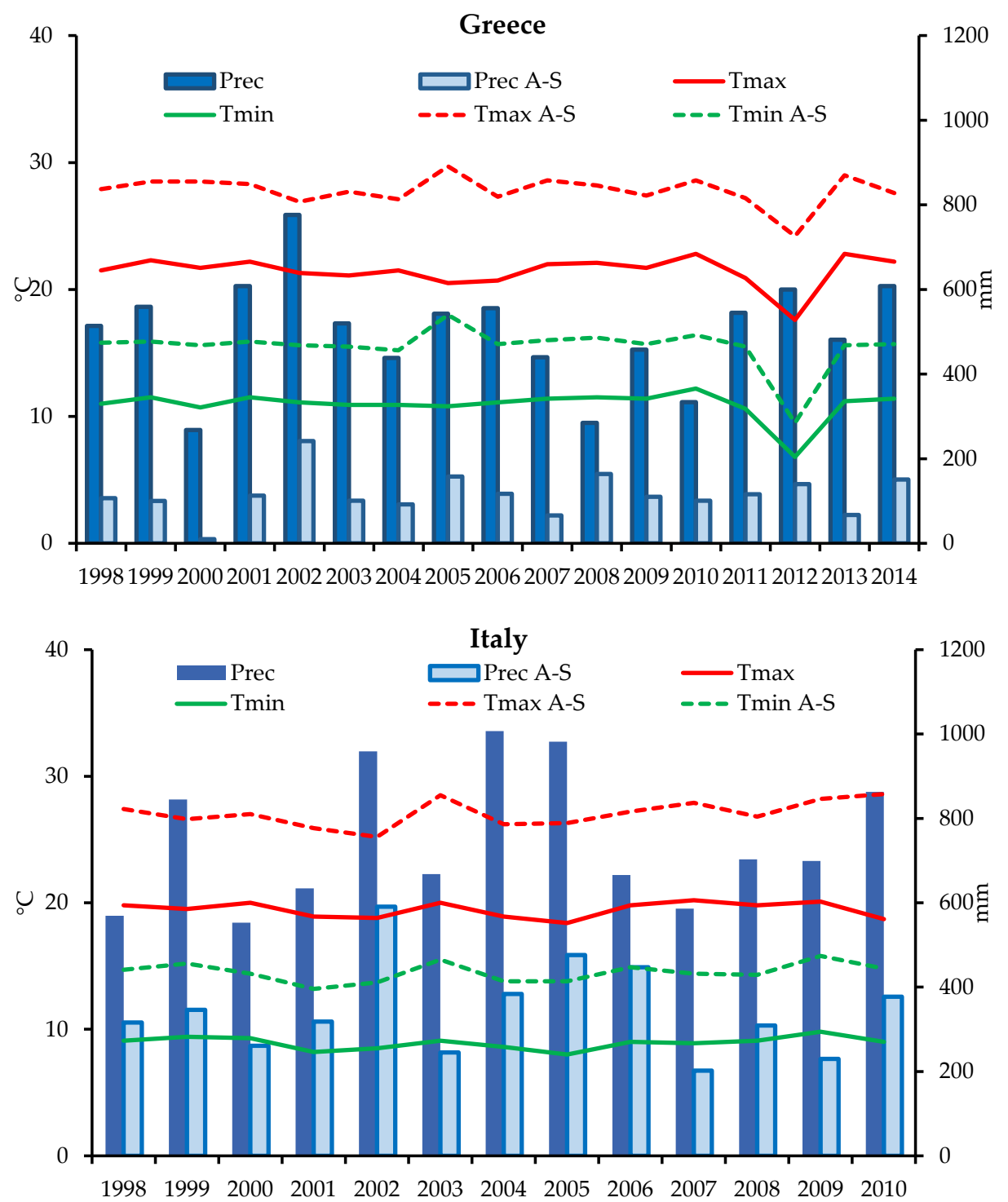

Figure 1. Meteorological parameters (1998-2014) in the switchgrass long-term screening trials in Greece at Aliartos (upper graph) and in Italy at Ozzano (below graph). Tmax $=$ mean annual maximum temperature $\left({ }^{\circ} \mathrm{C}\right)$; Tmin $=$ mean annual minimum temperature $\left({ }^{\circ} \mathrm{C}\right)$; Prec $=$ annual cumulative precipitation $(\mathrm{mm})$; Tmax A-S = mean maximum temperature from April to September $\left({ }^{\circ} \mathrm{C}\right)$; Tmin A-S = mean minimum temperature from April to September $\left({ }^{\circ} \mathrm{C}\right)$; Prec A-S = cumulative precipitation from April to September (mm).

\subsection{Data Collection}

In Greece, contemporaneously with harvest, the plant height, tiller density, and stem diameter were also measured. To measure the number of tillers per square meter, a marked area sized $0.5 \times 0.5 \mathrm{~m}$ in each plot was used. Harvest was carried out at both locations in winter (i.e., January/February), after the occurrence of killing frost, by manually cutting the entire biomass of a $4 \mathrm{~m}^{2}$ area in the central portion of each plot. Total biomass was weighed as fresh, and then a representative sub-sample $(500 \mathrm{~g})$ was oven dried at $80{ }^{\circ} \mathrm{C}$ until a constant weight was reached to determine the dry matter content. In Greece, a sub-sample of harvested biomass (of about $500 \mathrm{~g}$ ) was separated into stems and leaves. After the separation, stem and leaf sub-samples were oven-dried at $80^{\circ} \mathrm{C}$ until they reached a constant weight for dry matter determination. 


\subsection{Statistical Analysis}

For the data obtained in Greece, a one-way ANOVA was carried out to test the effect of variety and ecotype (upland vs. lowland) on all the surveyed parameters (i.e., the above ground biomass (AGB), dry stem weight (DSW), dry leaf weight (DLW), plant height (PH), stem diameter (STD), and tiller density (TILLER)), while the effect of year was considered as random. When the analysis of variance revealed significant differences $(P \leq 0.05)$, the Fisher's LSD test was used to separate means. A correlation analysis was run separately for upland and lowland ecotypes for all the parameters surveyed (i.e., the above ground biomass, dry stem weight, dry leaf weight, plant height, stem diameter, and tiller density) in the Greek study; when the correlation was found to be significant $(P \leq 0.05)$, the Pearson correlation coefficient was calculated. In Italy, due to uneven plant establishment and excessive weed pressure in two out of three replicates, all the measurements were carried out only once; for this reason, the Italian data were excluded from the statistical analysis and used only for comparison with the Greek results. The STATGRAPHICS 18 statistical software (Statgraphics Technologies, Inc., The Plains, VA, USA) was used for carrying out the data analysis.

\section{Results}

\subsection{Meteorological Conditions}

The meteorological conditions were adequate for sustaining switchgrass growth at both experimental sites. The common study years (1998-2010) at the two experimental sites were characterized, as expected, by different meteorological conditions (Figure 1). In general, Aliartos (Greece) was much drier and hotter than Ozzano (Italy), considering the whole year as well as during the period of the maximum development of switchgrass (April to September, [29]). The mean annual precipitation in the common years of the study was about $485 \mathrm{~mm}$ in Aliartos and about $750 \mathrm{~mm}$ in Ozzano. During the April-to-September period, the differences between the two locations were even more pronounced, with Ozzano having triple the precipitation of Aliartos (346 vs. $114 \mathrm{~mm}$ for Ozzano and Aliartos, respectively). In Greece, in the additional 4 years of the trial (2011-2014, Figure 1), precipitation was similar to pre-2010 levels ( $\sim 510 \mathrm{~mm}$ of cumulative annual precipitation and $\sim 115 \mathrm{~mm}$ of precipitation in the April-to-September period). Precipitation during the April-to-September period was highly variable across years in Aliartos, ranging from $10 \mathrm{~mm}$ in 2000 up to $242 \mathrm{~mm}$ in 2002; thus, additional supplemental irrigation was always applied to promote switchgrass growth. Temperatures differed between the two trial locations (Figure 1), with Aliartos showing a $+2.3^{\circ} \mathrm{C}$ mean minimum temperature and $\mathrm{a}+1.5^{\circ} \mathrm{C}$ mean maximum temperature compared with Ozzano. Considering the period of maximum development for switchgrass (April to September), differences in temperature were still evident, with $+2.2^{\circ} \mathrm{C}$ and $+1.1{ }^{\circ} \mathrm{C}$ differences in the maximum and minimum temperatures for Aliartos and Ozzano, respectively. In the additional 4 years of the trial in Aliartos, the temperatures were in line with those in the pre-2010 period, apart from in 2012, which was the coldest year in the previous 20 years (Figure 1).

\subsection{Switchgrass Productivity}

The tested switchgrass varieties were able to grow and produce sustained biomass yields ( $\geq 11 \mathrm{Mg} \mathrm{DM} \mathrm{ha}^{-1}$, mean annual yield for all the tested varieties) over the whole trial duration (17 years in Greece and 13 years in Italy), but it is worth mentioning that in Greece, switchgrass was irrigated during summer. The results of the ANOVA carried out only for the data collected in Greece are reported in Table 2.

Variety (main effect) proved to be significant $(p \leq 0.05)$ for the following surveyed parameters: above ground biomass (AGB), dry leaf weight (DLW), plant height (PH), tiller density (TILLER), and stem diameter (STD). The results for the AGB of switchgrass grown in Greece are reported in Figure 2. The varieties Alamo and Pangburn gave significantly higher biomass yields of 12.7 and $12.5 \mathrm{Mg} \mathrm{DM} \mathrm{ha}^{-1}$, respectively, compared with the varieties Cave-In-Rock (CIR), Kanlow, 
Caddo, Carthage, and SL 93-2, for which were reported lower yields of 10.1, 10.6, 10.9, 10.8, and 10.5 Mg DM ha ${ }^{-1}$, respectively. The biomass yield data for the Italian trial are reported in Figure 3. Alamo produced an average biomass yield of $16.6 \mathrm{Mg} \mathrm{DM} \mathrm{ha}^{-1}$ in the 13-year period of study, while Forestburg produced only an average biomass yield of $9.1 \mathrm{Mg} \mathrm{DM} \mathrm{ha}^{-1}$.

Table 2. ANOVA results for the main effects: variety and ecotype in the long-term screening trials at Aliartos (Greece) for the following surveyed parameters: AGB (above ground biomass, $\mathrm{Mg} \mathrm{DM} \mathrm{ha}^{-1}$ ), DSW (dry stem weight, Mg DM ha ${ }^{-1}$ ), DLW (dry leaf weight, $\mathrm{Mg} \mathrm{DM} \mathrm{ha}^{-1}$ ), PH (plant height, m), STD (stem diameter, mm), TILLER (tiller density, no. $\mathrm{m}^{-2}$ ).

\begin{tabular}{ccccccc}
\hline Factors & AGB & DSW & DLW & PH & STD & TILLER \\
\hline Variety & $*$ & ns & $*$ & $* *$ & $* *$ & $* *$ \\
Ecotype & ns & $*$ & ns & $* *$ & $* *$ & $*$ \\
\hline
\end{tabular}

ns $=$ not significant $,{ }^{*} P \leq 0.05,{ }^{* *} P \leq 0.01$.

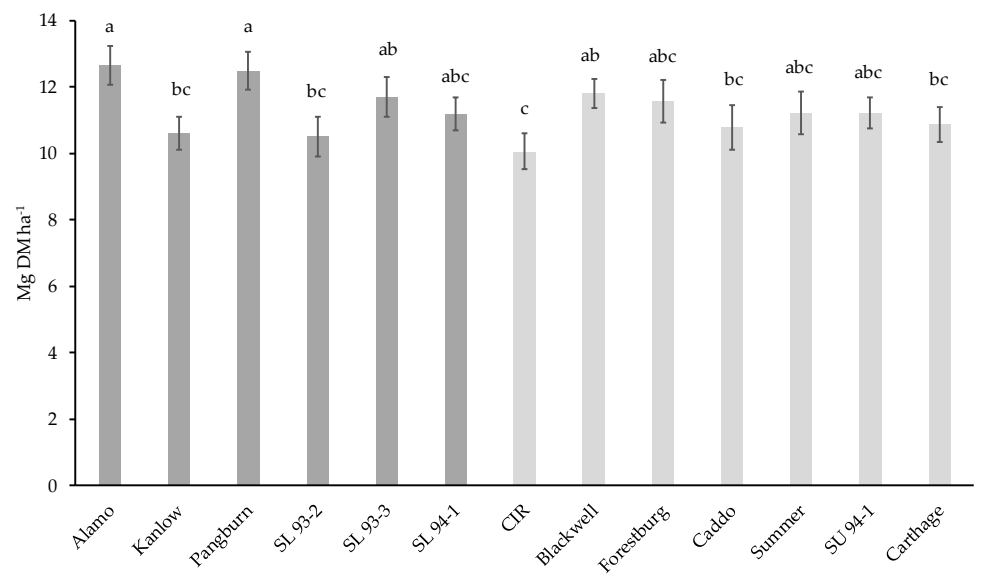

Figure 2. Above ground biomass yield $\left(\mathrm{Mg} \mathrm{DM} \mathrm{ha}^{-1}\right)$ of the 13 switchgrass varieties (dark grey histograms = lowland; light grey histograms = upland) grown at Aliartos (Greece) during the 1998-2014 period (main effect: variety). Vertical bars: standard error. Different letters: statistically significantly different means for $P \leq 0.05$ (LSD test).

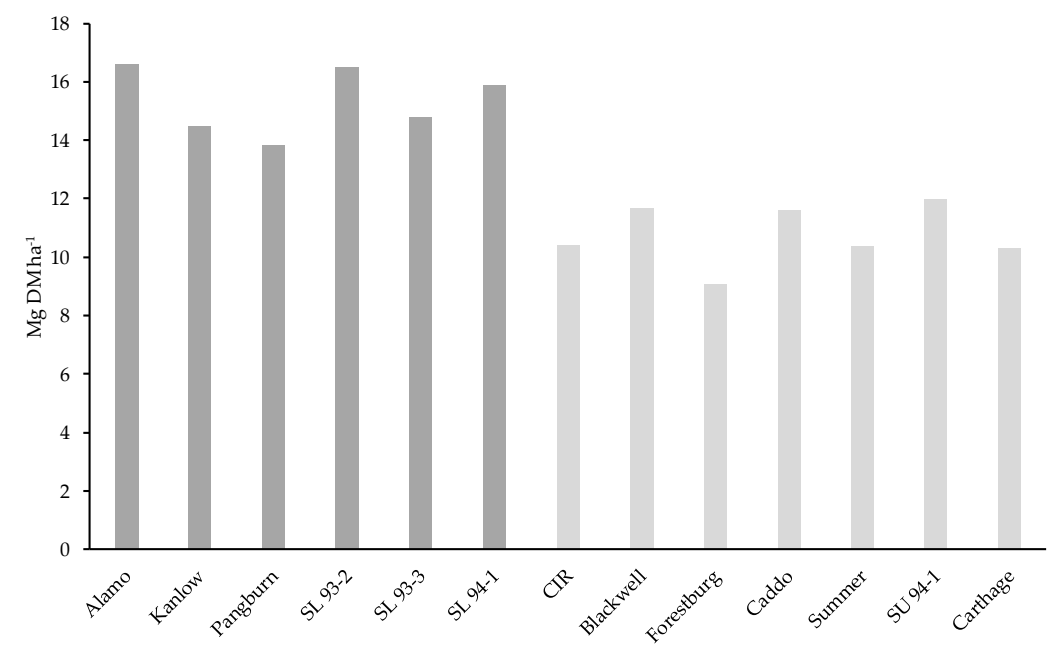

Figure 3. Above ground biomass yield $\left(\mathrm{Mg} \mathrm{DM} \mathrm{ha}^{-1}\right)$ of the 13 switchgrass varieties (dark grey histograms = lowland; light grey histograms = upland) grown at Ozzano (Italy) during the 1998-2010 period (main effect: variety). Vertical bars: confidence limits of the means for a confidence level of $95 \%$. 
It is worth remembering that the data from Italy are just from one replicate, thus making the comparison among varieties not statistically possible. In Greece, the ceiling AGB was reached between the second and fourth years after establishment (1999-2001), with mean yields almost $60 \%$ higher than the mean of the rest of the study years (16.6 vs. $10.1 \mathrm{Mg} \mathrm{DM} \mathrm{ha}^{-1}$ for the 1999-2001 vs. 2002-2014 period, respectively). In Italy, the switchgrass growth behavior was quite similar to that in Greece, but when comparing the coefficients of variation (CVs) among the tested varieties for the two locations (Figure 4), the variability was more pronounced for Italy, as expected due to the lack of proper replicates. The mean CVs for AGB were $36 \%$ and $43 \%$ in Greece and Italy, respectively.

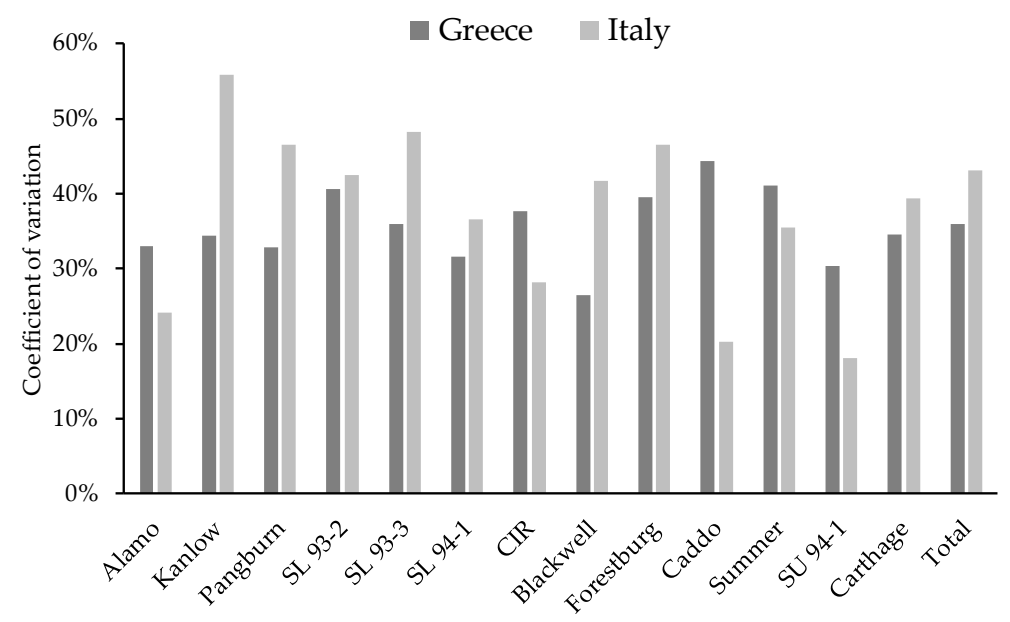

Figure 4. Coefficients of variation (\%) of above ground biomass yields of the 13 switchgrass varieties grown at Aliartos (Greece) during the 1998-2014 period and at Ozzano (Italy) during the 1990-2010 period.

The reported coefficients of variation for AGB were always above $25 \%$, confirming the high variability of switchgrass productivity across years, presumably in relation to meteorological conditions (Figure 1). Despite a statistical comparison between upland and lowland varieties not being possible across locations due to the lack of replicates in Italy, the mean AGB for uplands was $11.6 \mathrm{vs}$. $10.8 \mathrm{Mg} \mathrm{DM} \mathrm{ha}{ }^{-1}$ in Greece vs. Italy, respectively; otherwise, for lowlands, the mean AGB was 11.9 vs. $15.3 \mathrm{Mg} \mathrm{DM} \mathrm{ha}^{-1}$ in Greece vs. Italy, respectively.

In Greece, biomass partitioning was also carried out. As expected, the two components (stems and leaves) of switchgrass yield were found to be positively $(r=0.95)$ and significantly correlated $(p \leq 0.01)$. For the variety Alamo were reported the highest values for both DSW (7.6 Mg DM ha $\left.{ }^{-1}\right)$ and DLW (5.0 Mg DM ha $\left.{ }^{-1}\right)$, confirming its shoot vigor. Meanwhile, the variety CIR exhibited poor productive performance under the Greek climate, with the lowest values for both DSW (6.0 Mg DM ha ${ }^{-1}$ ) and DLW (4.1 Mg DM ha ${ }^{-1}$ ) being reported. Lowland varieties produced significantly more stem biomass (DSW) than upland, 6.9 vs. $6.5 \mathrm{Mg} \mathrm{DM} \mathrm{ha}^{-1}$ (main effect, ecotype; $P \leq 0.05$ ). In Greece, the plant height at harvest was significantly influenced by variety choice (Figure 5). Pangburn, Alamo, SL 94-1, Forestburg, and Summer were the tallest varieties, while Blackwell, CIR, Carthage, Caddo, and SL 93-3 were the shortest ones (Figure 5). As expected, the lowland varieties were taller than the upland ones (main factor, ecotype; $P \leq 0.05$ ), with reported average values of 1.56 vs. $1.47 \mathrm{~m}$, respectively. 


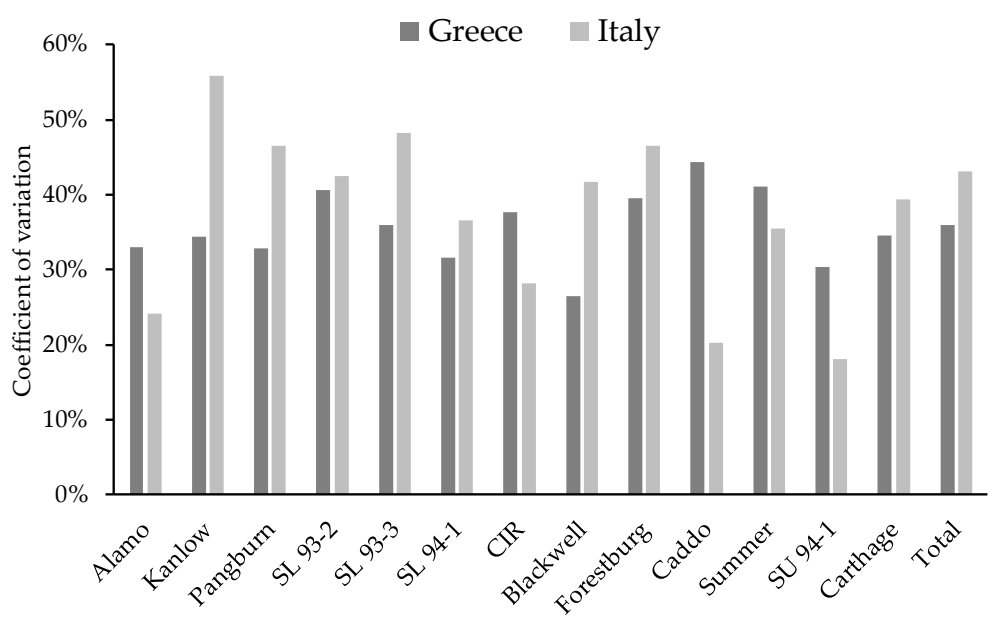

Figure 5. Mean plant height $(\mathrm{m})$ of the 13 switchgrass varieties (dark grey histograms = lowland; light grey histograms = upland) grown at Aliartos (Greece) during the 1998-2014 period (main factor: variety). Vertical bars: standard error. Different letters: statistically significantly different means for $P \leq 0.05$ (LSD test).

The results for tiller density in the Greek trial are reported in Figure 6. The upland variety, CIR, had the highest value, 945 tillers $\mathrm{m}^{-2}$; on the contrary, the lowland variety Pangburn had the lowest value (533 tillers $\mathrm{m}^{-2}$ ). In general, the upland ecotypes presented significantly higher tiller densities than the lowland ones (745 vs. 676 tillers $\mathrm{m}^{-2}$ for upland and lowland, respectively; $P \leq 0.05$ ). Tiller density was much higher during the establishment years $\left(>\sim 1200\right.$ tillers $\left.\mathrm{m}^{-2}\right)$ and the yield ceiling period (1998-2001); thereafter, the value remained almost constant at around 550 tillers $\mathrm{m}^{-2}$.

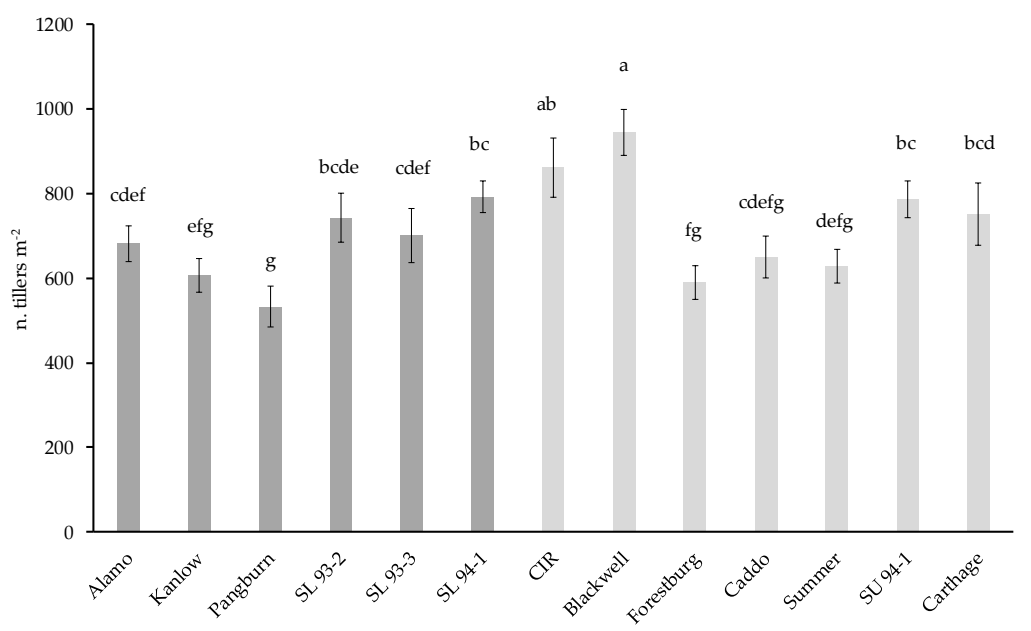

Figure 6. Mean tiller density (no. of tillers $\mathrm{m}^{-2}$ ) of the 13 switchgrass varieties (dark grey histograms $=$ lowland; light grey histograms = upland) grown at Aliartos (Greece) during the 1998-2014 period (main factor: variety). Vertical bars: standard error. Different letters: statistically significantly different means for $P \leq 0.05$ (LSD test).

In Greece, the plant stem diameter varied significantly among the tested switchgrass varieties (Figure 7), with Pangburn having a mean value of $3.64 \mathrm{~mm}$, significantly different from that of Blackwell ( $2.99 \mathrm{~mm}, P \leq 0.05)$. The lowland ecotypes showed larger diameters compared to the upland ones ( 3.40 vs. $3.15 \mathrm{~mm}$ for lowland vs. upland, respectively; $P \leq 0.05$ ). 


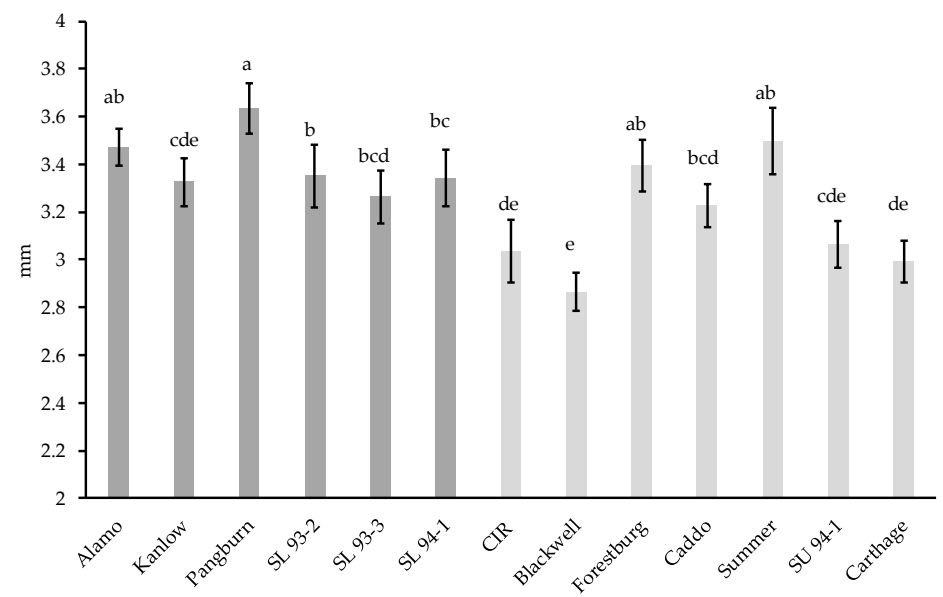

Figure 7. Mean plant stem diameter $(\mathrm{mm})$ of the 13 switchgrass varieties (dark grey histograms = lowland; light grey histograms = upland) grown at Aliartos (Greece) during the 1998-2014 period (main factor: variety). Vertical bars: standard error. Different letters: statistically significantly different means for $P \leq 0.05$ (LSD test).

The correlation analysis for all the surveyed parameters in the Greek trial is reported in Table 3 for the lowlands, and in Table 4 for the uplands. For the uplands, the stem diameter was positively related to AGB, DSW, and plant height, while in the lowlands, the diameter was also significantly correlated with plant height. For both ecotypes, the taller the plant, the thicker the stem. It is worth mentioning that the uplands were more prone to lodging than the lowlands; thus, presumably, the positive correlation between the biomass yield and diameter could be related to this aspect. Otherwise, the lowland varieties, which were characterized by thicker stems, showed a correlation between biomass yield and the diameter that was not significant, and they were never susceptible to lodging problems.

Table 3. Pearson moment coefficient for significant correlations at $P \leq 0.05$ among all the parameters surveyed in the switchgrass trial in Greece for lowland ecotypes. AGB (above ground biomass, $\mathrm{Mg} \mathrm{DM} \mathrm{ha}^{-1}$ ), DSW (dry stem weight, $\mathrm{Mg} \mathrm{DM} \mathrm{ha}^{-1}$ ), DLW (dry leaf weight, $\mathrm{Mg} \mathrm{DM} \mathrm{ha}^{-1}$ ), PH (plant height, $\mathrm{m}$ ), STD (stem diameter, mm), TILLER (tiller density, no. $\mathrm{m}^{-2}$ ), ns (not significant).

\begin{tabular}{ccccccc}
\hline & AGB & DSW & DLW & Plant Height & Diameter & TILLER \\
\hline AGB & & 0.95 & 0.89 & 0.30 & $\mathrm{~ns}$ & 0.42 \\
DSW & 0.95 & & 0.72 & 0.38 & $\mathrm{~ns}$ & 0.38 \\
DLW & 0.89 & 0.72 & & 0.12 & $\mathrm{~ns}$ & 0.40 \\
Plant height & 0.30 & 0.38 & 0.12 & & 0.37 & $\mathrm{~ns}$ \\
Diameter & $\mathrm{ns}$ & $\mathrm{ns}$ & $\mathrm{ns}$ & 0.37 & & $\mathrm{~ns}$ \\
TILLER & 0.42 & 0.38 & 0.40 & $\mathrm{~ns}$ & $\mathrm{~ns}$ & \\
\hline
\end{tabular}

Table 4. Pearson moment coefficient for significant correlations at $P \leq 0.05$ among all the parameters surveyed in the switchgrass trial in Greece for upland ecotypes.

\begin{tabular}{ccccccc}
\hline & AGB & DSW & DLW & Plant Height & Diameter & TILLER \\
\hline AGB & & 0.95 & 0.90 & 0.29 & 0.12 & 0.43 \\
DSW & 0.95 & & 0.74 & 0.40 & 0.15 & 0.40 \\
DLW & 0.90 & 0.74 & & ns & ns & 0.40 \\
Plant height & 0.29 & 0.40 & ns & & 0.28 & 0.18 \\
Diameter & 0.12 & 0.15 & ns & 0.28 & & ns \\
TILLER & 0.43 & 0.40 & 0.40 & 0.18 & ns & \\
\hline
\end{tabular}

AGB (above ground biomass, Mg DM ha ${ }^{-1}$ ), DSW (dry stem weight, $\mathrm{Mg} \mathrm{DM}_{\text {ha }}{ }^{-1}$ ), DLW (dry leaf weight,

$\mathrm{Mg} \mathrm{DM} \mathrm{ha}^{-1}$ ), $\mathrm{PH}$ (plant height, $\mathrm{m}$ ), STD (stem diameter, mm), TILLER (tiller density, no. $\mathrm{m}^{-2}$ ), ns (not significant). 


\section{Discussion}

The good potential of switchgrass to produce valuable lignocellulosic feedstock under a Mediterranean climate was confirmed [30,31]. Despite not being a native European species, in Greece, where the meteorological conditions permitted prolonged vegetative growth in relation to mild temperatures (Figure 1), switchgrass was able to achieve a sustained yield (>11 Mg DM ha ${ }^{-1}$, grand mean) for the whole trial duration (i.e., 17 years). However, this performance was supported by the adoption of an adequate agronomic management approach consisting of annual $\mathrm{N}$ fertilization, winter harvesting being carried out after killing frost, and irrigation. It is worth noting that the Greek study site was characterized by marginal soil, being a former lake bank, with sandy loam soil up to a $0.5 \mathrm{~m}$ depth and below only sand. Thus, the present results confirm that the use of an adequate agronomic management approach [32] could keep switchgrass biomass production at satisfactory levels for many years [13], also under marginal conditions [33], thus partially compensating the establishment costs that might be significant in the case of perennial crops [34,35]. The prolongation of switchgrass stand duration with time will presumably permit farmers to compensate the input cost, which should be carefully evaluated as reported by [34], in order to define the optimal agronomic management strategy for each specific environment. In Greece, even under adverse meteorological conditions-i.e., in 2000, 2004, 2007, and 2013 (Figure 1), when the precipitation in the April-to-September period was $<100 \mathrm{~mm}$ - the application of drip irrigation, together with adequate stand establishment (tiller density $>1000$ tillers $\mathrm{m}^{-2}$, as reported by [3]), permitted switchgrass to achieve sustained biomass production. A tiller density ranging between 800 to 1000 tillers $\mathrm{m}^{-2}$ is often reported as optimal in switchgrass for the control of weed pressure $[35,36]$. The adoption of irrigation should also be wisely considered in terms of management costs [11], but in semi-arid areas, like the southern part of the Mediterranean basin, it is often essential in order to achieve adequate yield, as extensively reported by [37-39]. The surveyed values for biomass yield in Greece were in line with those found in studies carried out under the same [4] or similar conditions $[6,30,36]$ but generally lower than those reported by [13] in a 20-year trial in Alabama (USA), where precipitation during the growing season often exceeded $900 \mathrm{~mm}$. The switchgrass biomass yield in the Italian trial corroborated the results found in Greece, even if a greater variability emerged among varieties and years, presumably in relation to the adoption of a very low input management approach (i.e., no fertilization and no irrigation), which did not "mitigate" the effect of the adverse seasonal climatic conditions. Interestingly, in both environments, the biomass yield ceiling was reached between the second and the third years after establishment, without any clear difference between the upland and lowland ecotypes. Otherwise, for some varieties, like Blackwell, which was the best performing upland variety in Greece, the yield trend across years was very stable, thus clearly evidencing its high suitability to the southern Mediterranean climate. The mean annual biomass yield ( $\left.11 \mathrm{Mg} \mathrm{DM} \mathrm{ha}^{-1}\right)$ reported for Greece is in line with that considered by [11] under marginal land in the Mediterranean region as the breakeven yield when associated with a biomass price of $65 \mathrm{EUR} \mathrm{Mg}^{-1}$. The latter price was identified as the breakeven biomass cost by [11] when adopting a high input management approach including irrigation and fertilization as in the present study, thus corroborating the economic sustainability of the presented results. A higher biomass price will obviously increase farmer revenue, but the volatility of the feedstock price makes this type of analysis quite challenging. In a previous study by [12], the biomass price of 55 EUR $\mathrm{Mg}^{-1}$ was associated with a breakeven yield of about $11 \mathrm{Mg} \mathrm{DM} \mathrm{ha}^{-1}$ for a 15 -year stand duration to compensate costs; thus, our results are also strongly in agreement with those values. If the mean annual yield of all the tested varieties exceeded $10.1 \mathrm{Mg} \mathrm{DM} \mathrm{ha}^{-1}$, it is worth mentioning that in specific years, some varieties-mainly uplands-reached values far below the above mentioned threshold. The variation of the mean biomass yields across years in Greece was relevant, ranging from 17.9 $\mathrm{Mg} \mathrm{DM} \mathrm{ha}{ }^{-1}$ in the second year to $8.8 \mathrm{Mg} \mathrm{DM} \mathrm{ha}^{-1}$ in the last year of trial. This finding makes the full estimation of the switchgrass stand sustainability very complicated but probably worthy of a dedicated and thorough economic study. 
The present screening trials, assessing the productive performance of upland and lowland switchgrass varieties grown in Greece and Italy, permitted direct comparisons between the upland and lowland ecotypes, which are still not extensively reported in the literature, as recently highlighted by [40]. Differences between the two ecotypes were evident only in Italy, with the lowlands leading to improved productive performance, even if the lack of replicates makes this result in need of further confirmation. This finding corroborated results reported by $[4,6,30]$ under similar climatic conditions, as well as those obtained by [13] and [38] under different locations across the USA. The lowland ecotypes, despite being later than the upland ones, benefited from the prolonged length of the growing season under the Mediterranean climate, where temperatures remain above $10{ }^{\circ} \mathrm{C}$ for the whole year and above $14^{\circ} \mathrm{C}$ in the April-to-September period. The lowlands were also resistant to lodging compared to the uplands in Greece, which often suffered from it. In Italy, the lowland ecotypes were able to produce significant biomass yields as well as to set seeds at northerner latitudes than $41^{\circ} \mathrm{N}$, in contrast to what was reported by [41], thus possibly expanding to the northern Mediterranean region the potential area for the future selection and breeding of new lowland varieties. Otherwise, it is worth mentioning that within the tested upland varieties, Blackwell presented productive performance similar to that of the best lowland varieties (i.e., Alamo and Pangburn), probably in relation to its outstanding capability $(+\sim 40 \%)$ to produce a high tiller density compared to all the other tested varieties (Figure 7). Interestingly, as reported by [42], since "genotype $x$ environment" plays a fundamental role in switchgrass adaptation and productivity, in the present study, the upland ecotypes grown in Greece demonstrated all their distinctive traits compared to the lowlands: shorter plants, thinner stems, and higher stem densities [14]. In contrast to the observations reported by [30], in the present study, the productive differences between the upland and lowland varieties were constantly maintained throughout the whole stand life-span, presumably in relation to the longer duration of the present study, which also included a very mature phase of switchgrass plantation.

\section{Conclusions}

The present study confirmed that the application of regular $\mathrm{N}$ fertilization and irrigation could allow sustained switchgrass biomass yields $\left(>\sim 11 \mathrm{Mg} \mathrm{DM} \mathrm{ha}^{-1}\right)$ for almost two decades in Greece, including under marginal conditions, i.e., shallow soil with low fertility that was fallow before the stand establishment. Any possible increase in the stand longevity, in the biomass yield, or in its price will guarantee for switchgrass a much more profitable economic scenario for Mediterranean farmers, but at this moment in time, we can consider it a feasible biomass crop, including under marginal soils. At both sites, the lowland varieties seemed to be more suitable to the local climate, thus demonstrating how the milder conditions of the Mediterranean region allow an adequate cycle length for the lowlands, which are normally later than the uplands.

Author Contributions: Conceptualization, E.A., F.Z., and A.M.; methodology, E.A.. and K.I.; software, F.Z.; formal analysis, F.Z.; investigation, E.A.; resources, E.A.; data curation, E.A.; writing-original draft preparation, F.Z.; writing—review and editing, E.A., A.M., and E.G.P.; supervision, E.A. and A.M.; funding acquisition, E.A. All authors have read and agreed to the published version of the manuscript.

Funding: This research has been partially funded by the European Commission under the FAIR program (FAIR 5 CT97 3701). The Greek study is part of the long-term trials included in the MAGIC project, which has received funding from the European Union's Horizon 2020 research and innovation program under grant agreement No 727698 .

Acknowledgments: The authors want to acknowledge Giuseppe Pritoni and Angela Vecchi for their precious help in carrying out the field trials in Bologna.

Conflicts of Interest: The authors declare no conflict of interest. 


\section{References}

1. McLaughlin, S.B.; Kszos, L.A. Development of switchgrass (Panicum virgatum) as a bioenergy feedstock in the United States. Biomass Bioenerg. 2005, 28, 515-535. [CrossRef]

2. Christian, D.G.; Elbersen, H.W. Switchgrass (Panicum virgatum L.). In Energy Plant Species. Their Use and Impact on Environment and Development; El Bassam, N., Ed.; Tailor \& Francis Ltd.: Abingdon, UK, 1998; pp. 257-263.

3. Alexopoulou, E.; Sharma, N.; Papatheohari, Y.; Christou, M.; Piscioneri, I.; Panoutsou, C.; Pignatelli, V. Biomass yields for lowland and upland varieties grown in the Mediterranean region. Biomass Bioenerg. 2008, 10, 926-932. [CrossRef]

4. Alexopoulou, E.; Zanetti, F.; Papazoglou, E.G.; Christou, M.; Papatheohari, Y.; Tsiotas, K.; Papamichael, I. Long-term studies on switchgrass grown on a marginal area in Greece under different varieties and nitrogen fertilization rates. Ind. Crop. Prod. 2017, 107, 446-452. [CrossRef]

5. Monti, A.; Venturi, P.; Elbersen, W. Evaluation of the establishment of lowland and upland switchgrass (Panicum virgatum $\mathrm{L}$.) varieties under different tillage and seedbed conditions in northern Italy. Soil Tillage Res. 2001, 63, 75-83. [CrossRef]

6. Monti, A.; Bezzi, G.; Pritoni, G.; Venturi, G. Long-term productivity of lowland and upland switchgrass cytotypes as affected by cutting frequency. Bioresour. Technol. 2008, 99, 7425-7432. [CrossRef]

7. Nocentini, A.; Di Virgilio, N.; Monti, A. Model simulation of cumulative carbon sequestration by Switchgrass (Panicum virgatum L.) in the Mediterranean area using the DAYCENT Model. Bioenerg. Res. 2015, 8, 1512-1522. [CrossRef]

8. Bhandari, H.S.; Walker, D.W.; Bouton, J.H.; Saha, M.C. Effects of ecotypes and morphotypes in feedstock composition of switchgrass (Panicum virgatum L.). GCB Bioenergy 2014, 6, 26-34. [CrossRef]

9. Blanco-Canqui, H. Growing dedicated energy crops on marginal lands and ecosystem services. Soil Sci. Soc. Am. J. 2016, 80, 845-858. [CrossRef]

10. Fernando, A.L.; Costa, J.; Barbosa, B.; Monti, A.; Rettenmaier, N. Environmental impact assessment of perennial crops cultivation on marginal soils in the Mediterranean region. Biomass Bioenerg. 2015, 111, 174-186. [CrossRef]

11. Soldatos, P. Economic Aspects of bioenergy production from perennial grasses in marginal lands of South Europe. Bioenerg. Res. 2015, 8, 1562-1573. [CrossRef]

12. Monti, A.; Fazio, S.; Lychnaras, V.; Soldatos, P.; Venturi, G. A full economic analysis of switchgrass under different scenarios in Italy estimated by BEE model. Biomass Bioenerg. 2007, 31, 177-185. [CrossRef]

13. Bransby, D.; Huang, P. Twenty-Year biomass yields of eight Switchgrass cultivars in Alabama. Bioenerg. Res. 2014, 7, 1186-1190. [CrossRef]

14. Casler, M.D. Ecotypic variation among switchgrass populations from the northern USA. Crop Sci. 2005, 45, 388-398. [CrossRef]

15. Hultquist, S.J.; Vogel, K.P.; Lee, D.J.; Arumuganathan, K.; Kaeppler, S. Chloroplast DNA and nuclear DNA content variations among cultivars of switchgrass, Panicum virgatum L. Crop Sci. 1996, 36, 1049-1052. [CrossRef]

16. Narasimhamoorthy, B.; Saha, M.C.; Swaller, T.; Bouton, J.H. Genetic diversity in switchgrass collections assessed by EST-SSR markers. Bioenerg. Res. 2008, 1, 136-146. [CrossRef]

17. Porter, C.L. An analysis of variation between upland and lowland switchgrass, Panicum virgatum L., in central Oklahoma. Ecology 1966, 47, 980-992. [CrossRef]

18. Alderson, J.; Sharp, W.C. Grass varieties in the United States. In Agricultural Handbook; USDA: Washington, DC, USA, 1993.

19. Gunter, L.E.; Tuskan, G.A.; Wullschleger, S.D. Diversity among populations of switchgrass based on RAPD markers. Crop Sci. 1996, 36, 1017-1022. [CrossRef]

20. Hopkins, A.A.; Taliaferro, C.M.; Murphy, C.D.; Christian, D.A. Chromosome number and nuclear DNA content of several switchgrass populations. Crop Sci. 1996, 36, 1192-1195. [CrossRef]

21. Taliaferro, C.M.; Hopkins, A.A. Breeding and Selecting of New Switchgrass Varieties for Increased Biomass Production; Five-year summary report; Oak Ridge National Laboratory: Oak Ridge, TN, USA, 1997.

22. Jung, G.A.; Shaffer, J.A.; Stout, W.L.; Panciera, M.T. Warm-season grass diversity in yield, plant morphology, and nitrogen concentration and removal in Northeastern USA. Agron. J. 1990, 82, 21-26. [CrossRef] 
23. Stout, W.L.; Jung, G.A.; Shaffer, J.A. Effects of soil and nitrogen on water use efficiency of tall fescue and switchgrass under humid conditions. Soil Sci. Soc. Am. J. 1988, 52, 429-434. [CrossRef]

24. Hein, M.A. Registration of varieties and strains of grasses. Agron. J. 1958, 50, 399-401. [CrossRef]

25. George, J.R.; Reigh, G.S. Spring growth and tiller characteristics of switchgrass. Can. J. Plant Sci. 1987, 67, 167-174. [CrossRef]

26. Barker, R.E.; Haas, R.J.; Jacobson, E.T.; Berdahl, J.D. Registration of 'Forestburg' switchgrass. Crop Sci. 1988, 28, 192-193. [CrossRef]

27. Metzger, M.J.; Bunce, R.G.H.; Jongman, R.H.G.; Mücher, C.A.; Watkins, J.W. A climatic stratification of the environment of Europe. Global Ecol. Biogeogr. 2005, 14, 549-563. [CrossRef]

28. Pedroso, G.M.; Van Kessel, C.; Six, J.; Putnam, D.H.; Linquist, B.A. Productivity, 15N dynamics and water use efficiency in low- and high-input switchgrass systems. GCB Bioenergy 2014, 6, 704-716. [CrossRef]

29. Heaton, E.A.; Voigt, F.G.; Long, S. A quantitative review comparing the yields of two candidate C4 perennial biomass crops in relation to nitrogen, temperature and water. Biomass Bioenerg. 2004, 27, 21-30. [CrossRef]

30. Nassi o Di Nasso, N.; Lasorella, M.V.; Roncucci, N.; Bonari, E. Soil texture and crop management affect switchgrass (Panicum virgatum L.) productivity in the Mediterranean. Ind. Crop. Prod. 2015, 65, 21-26. [CrossRef]

31. Zanetti, F.; Scordia, D.; Calcagno, S.; Acciai, M.; Grasso, A.; Cosentino, S.L.; Monti, A. Trade-off between harvest date and lignocellulosic crop choice for advanced biofuel production in the Mediterranean area. Ind. Crop. Prod. 2019, 138, 111439. [CrossRef]

32. Von Cossel, M.; Lewandowski, I.; Elbersen, B.; Staritsky, I.; Van Eupen, M.; Iqbal, Y.; Mantel, S.; Scordia, D.; Testa, G.; Cosentino, S.L.; et al. Marginal agricultural land low-input systems for biomass production. Energies 2019, 12, 3123. [CrossRef]

33. Scordia, D.; Cosentino, S.L. Perennial energy grasses: Resilient crops in a changing European agriculture. Agriculture 2019, 9, 169. [CrossRef]

34. Fike, J.H.; Pease, J.W.; Owens, V.N.; Farris, R.L.; Hansen, J.L.; Heaton, E.A.; Hong, C.O.; Mayton, H.S.; Mitchell, R.B.; Viands, D.R. Switchgrass nitrogen response and estimated production costs on diverse sites. GCB Bioenergy 2017, 9, 1526-1542. [CrossRef]

35. Scordia, D.; Zanetti, F.; Varga, S.S.; Alexopoulou, E.; Cavallaro, V.; Monti, A.; Copani, V.; Cosentino, S.L. New insights into the propagation methods of Switchgrass, Miscanthus and Giant Reed. Bioenerg. Res. 2015, 8, 1480-1491. [CrossRef]

36. An, Y.; Gao, Y.; Ma, Y. Growth performance and weed control effect in response to nitrogen supply for switchgrass after establishment in the semiarid environment. Field Crop Res. 2018, 221, 175-181. [CrossRef]

37. Nazli, R.I.; Tansi, V.; Öztürk, H.H.; Kusvuran, A. Miscanthus, switchgrass, giant reed, and bulbous canary grass as potential bioenergy crops in a semi-arid Mediterranean environment. Ind. Crop. Prod. 2018, 125, 9-23. [CrossRef]

38. Oliveira, J.A.; West, C.P.; Afif, E.; Palencia, P. Comparison of Miscanthus and Switchgrass cultivars for biomass yield, soil nutrients, and nutrient removal in Northwest Spain. Agron. J. 2017, 109, 122-130. [CrossRef]

39. Vamvuka, D.; Topouzi, V.; Sfakiotakis, S. Evaluation of production yield and thermal processing of switchgrass as a bio-energy crop for the Mediterranean region. Fuel Process. Technol. 2010, 91, 988-996. [CrossRef]

40. Aurangzaib, M.; Moore, K.J.; Lenssen, A.W.; Archontoulis, S.V.; Heaton, E.A.; Fei, S. Developmental morphology and biomass yield of Upland and Lowland switchgrass ecotypes grown in Iowa. Agronomy 2018, 8, 61. [CrossRef]

41. Casler, M.D.; Vogel, K.P. Selection for biomass yield in Upland, Lowland, and hybrid switchgrass. Crop Sci. 2014, 54, 626-636. [CrossRef]

42. Casler, M.D.; Sosa, S.; Boe, A.R.; Bonos, S.A. Soil quality and region influence performance and ranking of Switchgrass genotypes. Crop Sci. 2019, 59, 221-232. [CrossRef]

(C) 2020 by the authors. Licensee MDPI, Basel, Switzerland. This article is an open access article distributed under the terms and conditions of the Creative Commons Attribution (CC BY) license (http://creativecommons.org/licenses/by/4.0/). 